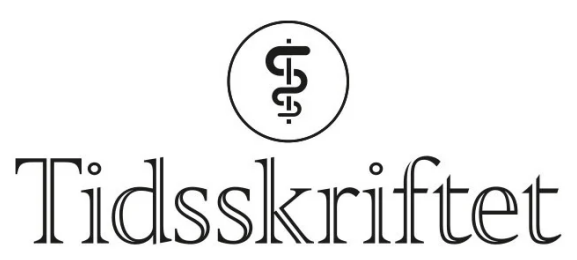

DEN NORSKE LEGEFORENING

\title{
Re: Helsebyen
}

\author{
BREV TIL REDAKTØREN
}

TORE AUDUN HØIE

Tore Audun Høie (f. 1942) er uavhengig konsulent innen ledelse, service, kvalitet, sikkerhet og standarder.

Ingen oppgitte interessekonflikter.

Email: tore.hoie@vikenfiber.no

I boken På helsa løs beskriver Eli Berg hvordan et økonomisk verdensbilde ble innført på Akershus universitetssykehus (1). Hun inkluderer en ordliste med økonomibegreper, i stor grad basert på masseproduksjon fra 1950-årene. I sin glimrende leder Helsebyen i Tidsskriftet nr. 1/2014 protesterer Charlotte Haug mot å bruke dette verdensbildet for helse (2 2 ). Hun foreslår at en storby er en bedre modell, og har selvfølgelig rett. En by leverer service til innbyggerne, i hvert fall skal den det. Den lager få produkter, og effektiviteten må defineres godt for at innbyggerne skal ha glede av den.

Jeg opplevde at helsereformen i 2002 i stor grad ble styrt av konsulenter fra USA, med tankegang fra masseproduksjon. De ville spare penger og innføre økonomiprinsipper. Jeg var involvert i prosessen, og en av mine oppgaver som selvstendig konsulent var å sikre at min klient innen Helse Sør fikk «lov til» å arbeide med kvalitet. Det var vanskelig. $\emptyset$ konomene kjente knapt begrepet og var bekymret for at kvalitet kunne koste penger.

Men Haug tar feil når hun henviser til japansk produksjon. Den er ulik USA-varianten, blant annet fordi nettopp kvalitet står sentralt i Japan (3,4.). Andre forskjeller gjelder kompetanse, fleksibilitet og samarbeid. Toppingeniører fikk et par måneder ved samlebåndet som introduksjon til Toyota, etterfulgt av en periode i salg. Noen få USAfirmaer gjorde tilsvarende, for eksempel IBM som i 1970-årene var ledende i verden innen en rekke områder. Men økonomistyringen fra masseproduksjon tok over også i IBM og forårsaket kanskje den nedturen de opplevde i 1980-årene.

General Motors og andre ble introdusert til japansk ledelse, men mye tyder på at de rett og slett ikke forsto tankegangen. Leger har også hatt vansker med å akseptere nye metoder: Det gikk 65 år fra det ble bevist at årelating er bortkastet, eller verre, til praksisen ble forlatt (5).

Også Toyota har møtt motbør og kan trenge nye metoder i en global, sammenfiltret verden. Konkurrenten Volkswagen definerte seg selv som servicebedrift i 1999. Kanskje dette er en bedre vei fremover? Bilen er ikke bare et produkt, den er et transportmiddel som bør starte hver dag og ikke tilbringe tiden på verksted. Min Audi fikk fem års garanti i 2002, General Motors innførte slik garanti først i 2008. Muligens stolte de ikke på egne produkter? 
Selv japansk produksjon er ikke egnet for et servicefag som helse. Serviceledelse er umiddelbart mer egnet. Men dette er en annen historie!

\section{LITTERATUR}

1. Berg E. På helsa løs. Økonomifokuset i norske sykehus. Oslo: Emilia, 2012.

2. Haug C. Helsebyen. Tidsskr Nor Legeforen 2014; 134: 5. [PubMed]

3. Womack JP, Jones DT, Roos D. The machine that changed the world. New York, NY: Rawson Associates, 1990.

4. Liker JK. The Toyota way. New York, NY: McGraw-Hill, 2004.

5. Lahnstein G. Noen glimt fra medisinfagets historie. Farsund: KLM-kompetanse og forlag, 2010.

Publisert: 25. mars 2014. Tidsskr Nor Legeforen. DOI: 10.4045/tidsskr.14.0282

(C) Tidsskrift for Den norske legeforening 2023. Lastet ned fra tidsskriftet.no 26. april 2023. 